\title{
ОЦЕНКА ВЛИЯНИЯ ДАПАГЛИФЛОЗИНА НА МАРКЕРЫ ХРОНИЧЕСКОЙ СЕРДЕЧНОЙ НЕДОСТАТОЧНОСТИ У БОЛЬНЫХ САХАРНЫМ ДИАБЕТОМ 2 ТИПА
}

\author{
${ }^{1}$ Мищенко Н.К., ${ }^{1,2}$ Маркова Т.Н., ${ }^{1}$ Мкртумян А.М., ${ }^{2}$ Синявкин Д.О.
}

'ГОУ ВПО «Московский государственный медико-стоматологический университет имени А.И.Евдокимова», Москва гГБУз города Москвы «Городская клиническая больница № 52 ДЗМ», Москва

ЦЕЛЬ: оценить влияние дапаглифлозина (ДАПА) на уровень гликированного гемоглобина $\left(\mathrm{HbA}_{1 c}\right)$, концентрацию N-концевого предшественника мозгового натрийуретического пептида (NT-proBNP), показатель конечного диастолического размера (КДР) и уровень артериального давления (АД) у больных сахарным диабетом 2 типа (СД2).

МАТЕРИАЛЫ И МЕТОДЫ: в исследование включено 48 пациентов (21 женщина и 27 мужчин) с СД2 с сохранной фракцией выброса (62\% [55;66]), получающих метформин (2000 мг/сутки) и препараты сульфонилмочевины (СМ). Стаж диабета составил 9 лет [5,0;12,0]. В основную группу включено 25 пациентов в возрасте 62 лет [57;66], в контрольную группу - 23 пациента в возрасте 62 лет [52;68]. Хроническая сердечная недостаточность (XCH) по уровню NT-proBNP и наличию диастолической дисфункции выявлена у $32 \%(8 / 25)$ пациентов основной группы и у $26 \%(6 / 23)$ пациентов контрольной группы (р>0,05). Пациентам основной группы к исходной терапии добавлен ДАПА в дозе 10 мг/сутки. Оценка динамики концентрации HbA1c, содержания NT-proBNP, параметра КДР по данным эхокардиографии, уровня среднесуточного систолического (САД) и диастолического АД (ДАД) по данным суточного мониторирования АД проводилась исходно и через 6 месяцев.

РЕЗУЛЬТАТЫ: через 6 месяцев в основной группе уровень $\mathrm{HbA}_{1 с}$ снизился с 8,7\% [7,8;9,2] до 7,5\% $[6,7 ; 8,2](p=0,0001)$, в группе сравнения - c 7,7\% $[6,9 ; 8,1]$ до 7,4\% $[6,8 ; 9,3](p=0,55)$. В основной группе содержание NT-proBNP уменьшилось с 76 нг/л [40;126] до 47 нг/л [29;127] (p=0,11), в контрольной группе - с 74 нг/л [47;121] до 59 нг/л [40;128] (p=0,33). На фоне терапии ДАПА в группе пациентов с СД2 и XCH зафиксировано достоверное снижение уровня NT-proBNP с 189 нг/л [138;212] до 108 нг/л [61;208] $(\mathrm{p}=0,036)$. В группе пациентов с СД2 и XCH, получающих терапию МЕТ и препаратами СM, уровень NTproBNP исходно составил 193 нг/л [139;791], через 6 месяцев - 183 нг/л [81;567] ( $p=0,068)$. В основной группе параметр КДР уменьшился с 49 мм [48;56] до 47 мм [43;50] ( $p=0,04)$, уровень САД с 128 мм рт.ст. [128;140] до 125 мм рт.ст.[120;132] ( $=0,014)$ и уровень ДАД с 78 мм рт.ст.[73;85] до 77 мм рт.ст.[73;80] $(p=0,49)$. В контрольной группе параметр КДР исходно составил 51 мм [46;53], через 6 месяцев - 50 мм [47;54], уровни САД и ДАД исходно - 127 мм рт.ст.[123;140] и 78 мм рт.ст.[73;85], через 6 месяцев 134 мм рт.ст.[122;141] и 78 мм рт.ст.[76;86], р>0,05 во всех случаях. По данным корреляционного анализа не выявлено взаимосвязи между показателями углеводного обмена и маркерами ХСН в основной группе: уровень $\mathrm{HbA}_{1 c}$ не зависел от концентрации NT-proBNP $(r=0,26, p=0,21)$ и параметра KДP $(r=0,15$, $\mathrm{p}=0,48)$. В подгруппе пациентов с СД2 и XCH получены аналогичные результаты: уровень НbA 1 не коррелировал с концентрацией NT-proBNP $(r=0,25, p=0,55)$ и параметром KДP $(r=0,22, p=0,61)$. Также, в основной группе не выявлено взаимосвязи между показателем НbA1с и уровнем САД $(r=-0,09, p=0,68)$.

ВЫВОДЫ: назначение ДАПА больным СД2, получающим комбинированную терапию МЕТ и препаратами СМ, сопровождается снижением показателя НbA1c, параметра КДР и уровня САД, уменьшением концентрации NT-proBNP в подгруппе пациентов с СД2 и ХCH. Влияние ДАПА на маркеры ХСН и уровень АД связано с механизмом действия препарата, а не со снижением уровня гликированного гемоглобина.

КЛЮЧЕВЫЕ СЛОВА: сахарный диабет 2 типа; дапаглифлозин; N-концевой предшественник мозгового натрийуретического пептида; конечный диастолический размер; среднесуточное артериальное давление. 